\title{
Brain-Derived Neurotrophic Factor Supports the Survival of Cultured Rat Retinal Ganglion Cells
}

\author{
James E. Johnson, Yves-Alain Barde, Martin Schwab, ${ }^{1}$ and Hans Thoenen \\ Department of Neurochemistry, Max-Planck-Institute for Psychiatry, 8033 Martinsried, Federal Republic of \\ Germany
}

Brain-derived neurotrophic factor (BDNF) is a small, basic protein purified from the mammalian brain that has been shown previously to support the survival of cultured spinal sensory neurons (Barde et al., 1982). In current studies, BDNF was tested for its ability to support the survival of cultured CNS cells isolated from the perinatal rat retina. Both immunofluorescent labeling of Thy-1 and prior retrograde labeling with HRP were used as retinal ganglion cell markers in vitro. With embryonic day (E) 17 retinas, it was found that BDNF allowed the survival of a small subpopulation of neurons (about $7 \%$ of the cells plated at this age) identified by the immunofluorescent labeling of Thy1. No detectable effects were seen when either the total number of cells or the number of tetanus toxin-positive neurons was measured. BDNF also had an effect on cultured neurons retrogradely labeled after HRP injections in the superior colliculi of neonatal rats. The BDNF-responsive population was therefore detected only in retinal cultures with specific markers and identified as consisting of retinal ganglion cells. These cells could be enriched about 80 -fold by density gradient centrifugation, and purified ganglion cell cultures were shown to be responsive to BDNF. Whereas with E17 retinas, the number of surviving Thy-1 positive neurons could be kept constant for at least $4 \mathrm{~d}$, the survival of postnatal neurons was only transiently increased by BDNF.

We conclude that in the retina, BDNF affects only the survival of ganglion cells in vitro by a direct action on these cells. The results are discussed in terms of target-derived neurotrophic support during development.

The death of a substantial proportion of many different types of neurons is a common feature of the normal development of the vertebrate nervous system. It is generally believed to serve in the appropriate quantitative matching of a neuronal population with its respective terminal field (Cowan et al., 1984).

In vertebrates, evidence for the epigenetic regulation of neuronal cell death in the CNS as well as in the PNS has arisen from both target transplantation and ablation experiments. There is good evidence for molecular agents that serve to regulate neuronal cell death, the clearest being provided by the protein nerve growth factor (NGF). Treatment of developing mammals with antibodies against NGF results in the selective elimination of a large proportion of the peripheral sympathetic and sensory neurons. On the other hand, the treatment of animals with

\footnotetext{
Received Jan. 7, 1986; revised Apr. 7, 1986; accepted Apr. 11, 1986.

We wish to thank Dr. Hermann Rohrer for helpful suggestions and Mrs. C. Cap for technical assistance. This work was supported in part by fellowships from the Alexander von Humboldt Foundation, the Kempton Foundation and an NRSA from NIH, NINCDS (PHS-5F32-NSO7332-02X1) awarded to J.E.J.

Correspondence should be addressed to Dr. James E. Johnson, Abteilung Neurochemie, Max-Planck-Institut für Psychiatrie, Am Klopferspitz 18a, $8033 \mathrm{Mar}$ tinsried bei München, Federal Republic of Germany.

Present address: Institut für Hirnforschung der Universität Zürich, AugustForel-Strasse 1, CH-8029 Zürich, Switzerland.

Copyright (c) 1986 Society for Neuroscience $0270-6474 / 86 / 103031-08 \$ 02.00 / 0$
}

exogenous NGF rescues many neurons in these ganglia that would otherwise dic during development (for revicws, sce Grecne and Shooter, 1981; Levi-Montalcini and Angeletti, 1968; Thoenen and Barde, 1980). Results from in vitro assays have indicated that several other proteins with a similar function, but a different specificity might exist (Barde et al., 1983; Berg, 1984; Thoenen and Edgar, 1985). One of these proteins has been purified from the mammalian brain (Barde et al., 1982). This brainderived neurotrophic factor (BDNF) has a molecular weight of $12,000 \mathrm{Da}$ and an isoelectric point of about 10. It is known to support the survival of a variety of primary sensory neurons (connected to the CNS by their central axons) and to be inactive on both ciliary and sympathetic neurons (Barde et al., 1982; Davies et al., 1986; Lindsay et al., 1985).

The current studies were conducted to determine if there is a population of CNS neurons that responds to BDNF in culture. The retina was chosen for these studies since we have previously shown that an extract prepared from pig brain stimulates neurite outgrowth from fetal rat retinal explants in culture (Turner et al., 1983). In addition, with dissociated rat retinas, it is possible to identify ganglion cells in vitro using the surface glycoprotein Thy-1 as a marker or after retrogradely labeling the cells with HRP (Armson and Bennett, 1983; Beale and Osborne, 1982; Beale et al., 1983; McCaffery et al., 1982, 1984, 1985; Sarthy et al., 1983). A large number of these cells normally die during the development of the innervation of their target regions in the brain (Braekevelt and Hollenberg, 1970; Crespo et al., 1985; Dreher et al., 1983; Fawcett et al., 1984; Insausti et al., 1984; Morest, 1976; Potts et al., 1982). Previous studies have indicated that tissue extracts, coculture, or conditioned media from the target area of the retinal ganglion cells contain survival activity for these cells in vitro (Armson and Bennett, 1983; Nurcombe and Bennett, 1981). The results presented in this study suggest that this requirement might be met by BDNF.

\section{Materials and Methods}

\section{Retinal cell cultures}

All experiments were conducted with albino Wistar rats. Retinas were removed from fetal rat pups on embryonic day (E) 17 or from postnatal pups within $48 \mathrm{hr}$ after birth. Pregnant females were anesthetized with ether, and embryos were collected on ice. The age of the cmbryos was determined by a measurement of the total body wet weight as described by Schneidereit (1985). Only animals weighing $0.6 \pm 0.15 \mathrm{gm}$ were used in experiments with E17 retinas. About 20 retinas were collected for each experiment, washed in $15 \mathrm{ml}$ of calcium- and magnesium-free PBS, and incubated in $10 \mathrm{ml}$ PBS containing $0.05 \%$ trypsin (Worthington) and $0.01 \% \mathrm{DNase}$ (Sigma) for $15 \mathrm{~min}$ at $37^{\circ} \mathrm{C}$. Retinas from postnatal pups were treated with $0.1 \%$ trypsin under otherwise identical conditions. After proteolytic digestion, retinas were washed in $15 \mathrm{ml}$ F14 containing 10\% (vol/vol) heat-inactivated horse serum (GIBCO; F14-HS). They were subsequently dissociated by gentle pipetting in 2 $\mathrm{ml}$ of fresh F14-HS. Large undissociated pieces of retina were allowed to sediment, and the cell suspension was carefully removed and resuspended in an additional $3 \mathrm{ml}$ of fresh F14-HS. Trypan blue-negative 
cells were counted with a hemocytometer. All culture dishes were coated overnight with a sterile solution of polyornithine (Type 1-B, Sigma) (Collins, 1978), washed twice with sterile water, and finally coated for $2 \mathrm{hr}$ with laminin (Bethesda Research Laboratories: $25 \mu \mathrm{g} / \mathrm{ml}$ PBS, 80 $\mu \mathrm{l} / \mathrm{culture}$ well). Laminin-coated dishes were then washed twice with PBS before the addition of F14-HS. Culture dishes contained 4 individual wells $(10 \mathrm{~mm}$ diameter) for immunofluorescent staining (Type 627170; Greiner, Nürtingen).

Two hundred thousand cells were added to each $35 \mathrm{~mm}$ culture dish containing $1.5 \mathrm{ml}$ of F14-HS. Retinal cells were cultured with or without either BDNF or NGF as indicated. BDNF was purified from porcine brain according to the method described by Barde et al. (1982) using the modifications described by Lindsay et al. (1985). NGF and F14 culture medium were prepared as described by Barde ct al. (1980).

\section{Thy-1 localization}

Thy-1 was localized on live cultured retinal cells with indirect immunofluorescence utilizing mouse monoclonal IgG antibodies against the rat Thy-1.1 antigen [Ox 7, Seratech, ascites diluted 1:20 in Krebs buffer containing $0.5 \%$ BSA (K-BSA) for $40 \mathrm{~min}$ at $20^{\circ} \mathrm{C}$ ]. Both FITC conjugated goat antimouse IgG (Miles) and RITC conjugated rabbit antimouse IgG (Dakopatts, Denmark) were used in separate experiments as secondary antibodies $\left(1: 50,20 \mathrm{~min}\right.$ at $\left.20^{\circ} \mathrm{C}\right)$. Cultures were coverslipped in PBS-glycerol (1:1) and examined with a Leitz Orthoplan microscope equipped with phase-contrast and epi-uv illumination. Control immunofluorescence was performed either by omitting the primary antibody or by a substitution with normal mouse IgG or mouse serum (1:100). No specific fluorescence was seen under these control conditions. Retinal cultures and $20 \mu \mathrm{m}$ frozen sections of neonatal rat retinas were alsc prepared for Thy- 1 immunofluorescence after fixation in $4 \%$ paraformaldehyde utilizing identical staining conditions. Live retinal cultures were routinely used for Thy-1 localization since prior fixation resulted in a considerable loss of Thy- 1 antigenicity, as reported by others (Morris and Barber, 1983).

\section{Tetanus toxin binding and nuclear staining}

Retinal cells were stained for tetanus toxin receptors using the indirect immunofluorescence method of Mirsky et al. (1978). Briefly, live cultures were incubated sequentially with tetanus toxin $(25 \mu \mathrm{g} / \mathrm{ml} \mathrm{K}$-BSA) and human anti-tetanus toxin immunoglobulin (1:50) (Behring-Werke, Marburg) for 20 min each. Cultures were then fixed with $4 \%$ paraformaldehyde and subsequently incubated with FITC-labeled goat antihuman immunoglobulins (1:50) (Behring-Werke, Marburg). Tetanus toxin was a gift from Dr. B. Bizzini (Institut Pasteur, Paris). Cultures stained for tetanus toxin binding were also processed for Thy-1 localization using RITC-labeled secondary antibodies as previously described. In addition, the nuclei of all cultured retinal cells were subsequently stained with the fluorescent dye bisbenzimide $(\mu \mathrm{g} / \mathrm{ml}$ PBS Hoechst No. 33258, Sigma). Bisbenzimide fluorescence was visible at an excitation wavelength of $340-380 \mathrm{~nm}$ and was not visible on either FITC (450-490 nm) or RITC $(530-560 \mathrm{~nm})$ fluorescent channels.

\section{${ }^{3} \mathrm{H}$-thymidine uptake}

Cells dissociated from E17 retinas were cultured with or without BDNF in F14-HS containing $1 \mu \mathrm{Ci} / \mathrm{ml}^{3} \mathrm{H}$-thymidine [(methyl- $\left.{ }^{3} \mathrm{H}\right)$-thymidinc; $79.8 \mathrm{Ci} / \mathrm{mmol}$; New England Nuclear]. Fresh ${ }^{3} \mathrm{H}$-thymidine was added daily to retinal cultures grown for either 2 or $4 \mathrm{~d}$. Cultures were then processed for Thy-1 localization and fixed as previously described. Fixed cultures were then rapidly dehydrated, to avoid fluorescent quenching, through 2 changes of $70 \% \mathrm{EtOH}, 96 \% \mathrm{EtOH}$, and absolute $\mathrm{EtOH}$ and subsequently air-dried for $20 \mathrm{~min}$ in dark desiccation chambers. Desiccated cultures were then coated with emulsion NTB2 (Kodak) and incubated in dark desiccation chambers for $5 \mathrm{~d}$ at $4^{\circ} \mathrm{C}$. Cultures were subsequently processed for autoradiography and examined for Thy-1 immunofluorescence and ${ }^{3} \mathrm{H}$-thymidine uptake.

\section{HRP labeling}

Retinal ganglion cells were retrogradely labeled in newborn animals with HRP as described elsewhere (Dreher et al., 1983; Potts et al., 1982). Newborn rats were injected with HRP within $24 \mathrm{hr}$ after birth. Rat pups were anesthetized on ice, and $1 \mu l$ of $30 \%$ HRP (Type VI, Sigma) was injected with a $5 \mu \mathrm{l}$ Hamilton syringe bilaterally into the superior colliculi. Injected pups were warmed for $2 \mathrm{hr}$ and subsequently returned to their mothers, which were briefly anesthetized with ether. Maternal anesthesia greatly enhanced the acceptance of injected pups. Retinas were removed from HRP-injected animals after $24 \mathrm{hr}$. They were either fixed in $4 \%$ paraformaldehyde for histologic study or dissociated for retinal cell cultures as previously described. The specific retrograde transport of IIRP by ganglion cells was verified in both $20 \mu \mathrm{m}$ sections and retinas whole-mounted after HRP histochemistry with $0.5 \% 2,3$ diaminobenzidine (DAB) (LaVail and LaVail, 1975) and intensified with $0.4 \%$ nickel ammonium sulfate and $0.6 \%$ cobalt chloride. A subpopulation of retinal ganglion cells was heavily labeled with reaction product, while other ganglion cells were weakly labeled or unlabeled. Cultures prepared from retinas taken from injected animals were fixed and stained for HRP-labeled ganglion cells with tetramethylbenzidine (TMB) according to the method of Mesulam (1978).

\section{Retinal ganglion cell purification}

Ganglion cells were partially purified from other cells dissociated from newborn rat retinas by the modification of a method utilizing gradient centrifugation previously reported by Sarthy et al. (1983). Cell suspensions were prepared from 20 retinas as above, except that retinas washed with $\mathrm{F} 14-\mathrm{HS}$ after proteolytic digestion were then subsequently washed twice in F14 without serum and dissociated in $12 \mathrm{ml} \mathrm{F14}\left(4^{\circ} \mathrm{C}\right)$. Six milliliters of $30 \%$ metrizamide (wt/vol) (Serva, Heidelberg) in F14 $\left(4^{\circ} \mathrm{C}\right.$ ) was then mixed with the cell suspension, which was distributed equally into 2 centrifuge tubes. The purification of ganglion cells was best achieved when the final density of cells in the $10 \%$ metrizamide solution was less than $3 \times 10^{6}$ cells $/ \mathrm{ml}$. This cell suspension was gently overlaid with $4 \mathrm{ml}$ of $5 \%$ metrizamide, and the step gradient was spun in a Sorvall $\mathrm{HB}-4$ rotor for $25 \mathrm{~min}$ at $4500 \mathrm{rpm}(3300 \times \mathrm{g})$ at $4^{\circ} \mathrm{C}$. Ten $1 \mathrm{ml}$ aliquots were collected from each tube and examined for the size and homogeneity of cells. The first 3 aliquots collected from the $5-10 \%$ interface were routinely pooled and washed with $20 \mathrm{ml}$ of fresh $\mathrm{F} 14\left(4^{\circ} \mathrm{C}\right)$. Collected cells were gently pelleted by centrifugation at $60 \times \mathrm{g}$ for $10 \mathrm{~min}$ and then resuspended in F14-HS and cultured on laminin-coated dishes as described above. An analysis of ganglion cell purification was possible using both Thy- 1 localization and retrograde transport of HRP as a marker for ganglion cells. The number of ganglion cells was determined $3 \mathrm{hr}$ after seeding (time 0 ) and in cultures grown for either 2 or $4 \mathrm{~d}$ in the presence or absence of BDNF.

\section{Results}

\section{Fetal retinal cultures}

Cells dissociated from E17 retinas attached rapidly and were randomly distributed as individual cells on the laminin-coated substrates. Laminin provided a better substrate for retinal neuritc growth and survival than type I collagen, fibronectin, or poly (DL-ornithine) (results not shown), as indicated by others (Adler et al., 1985; Smalheiser et al., 1984). Many retinal neurons began developing neurite outgrowth during the first few hours on a laminin substrate, irrespective of the presence or absence of BDNF (Figs. 1 $A, 2 A$ ). These cultures contained a mixture of both flat non-neuronal cells and a heterogenous population of retinal neurons, some with long processes (Figs. $1 C$, $2 C$ ). The total number of nuclei stained with the fluorescent dye bisbenzimide (Figs. $1 B, 2 B$ ) was counted. No difference was

Figure 1. Dissociated cells from E17 rat retinas cultured for $3 \mathrm{~d}$ in the absence of BDNF. The same field was photographed with phase microscopy $(A)$, blue bisbenzimide fluorescence of cell nuclei $(B)$, green FITC-immunofluorescence of tetanus toxin binding to retinal neurons $(C)$, or red RITCimmunofluorescence of a subpopulation of neurons labeled for Thy-1 $(D)$. Note that control cultures contain both a large number of retinal cells $(A, B)$ and a large number of neurons $(C)$ in the absence of BDNF. In contrast, the subpopulation of Thy-1-positive neurons is virtually absent in control cultures $(D)$. Bar (in $A$ ), $100 \mu \mathrm{m}$. 

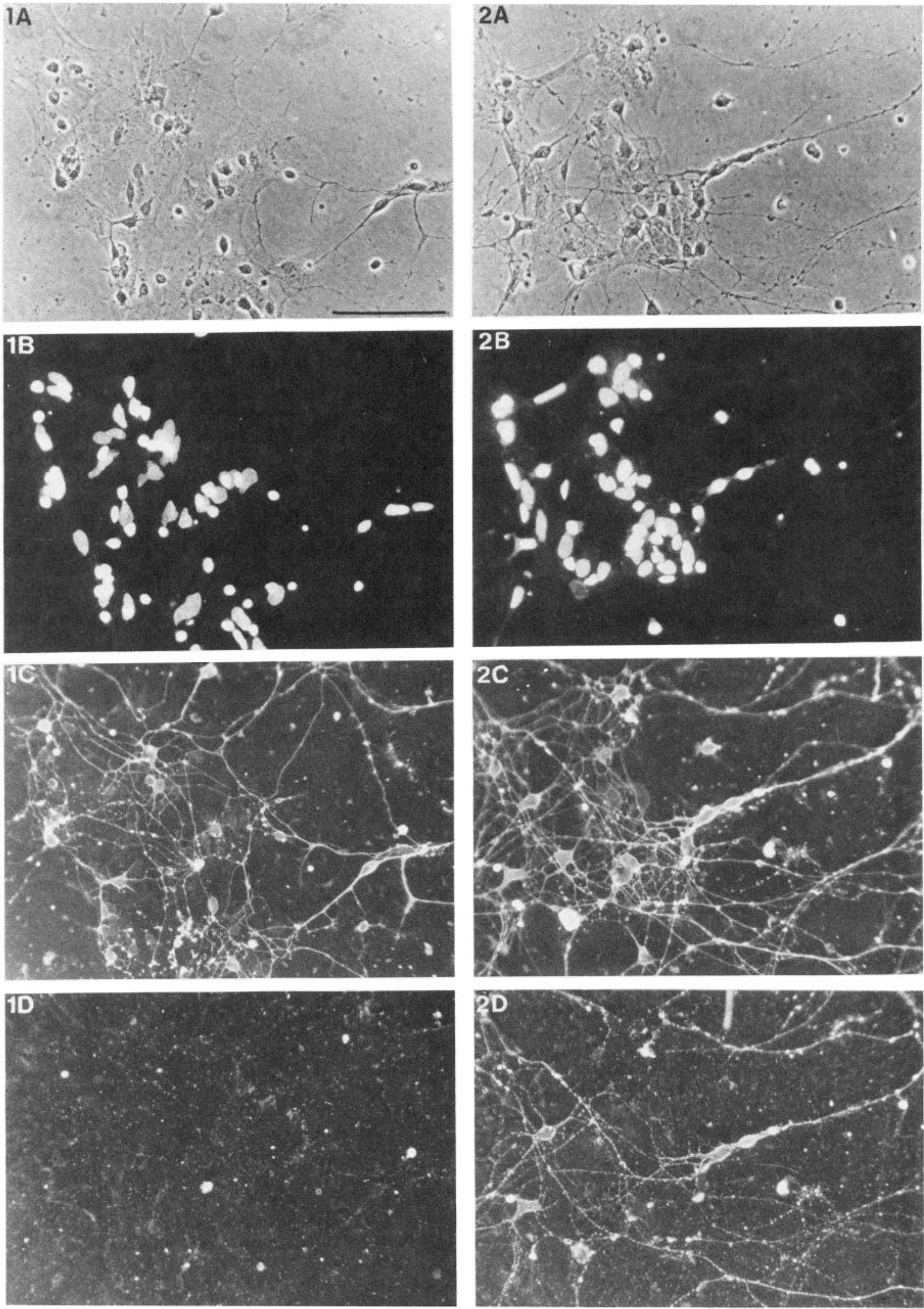

Figure 2. E17 retinal cells cultured for $3 \mathrm{~d}$ in the presence of BDNF $(50 \mathrm{ng} / \mathrm{ml})$ and photographed under identical conditions as in Figure 1 . Note that few differences can be seen with control cultures in either the total population of cultured retinal cells $(A, B)$ or in the total neuronal population $(C)$. However, a subpopulation of neurons identified by Thy-1 immunofluorescence $(D)$ is seen when cultures are treated with BDNF and is virtually absent in control cultures (Fig. 1D). 

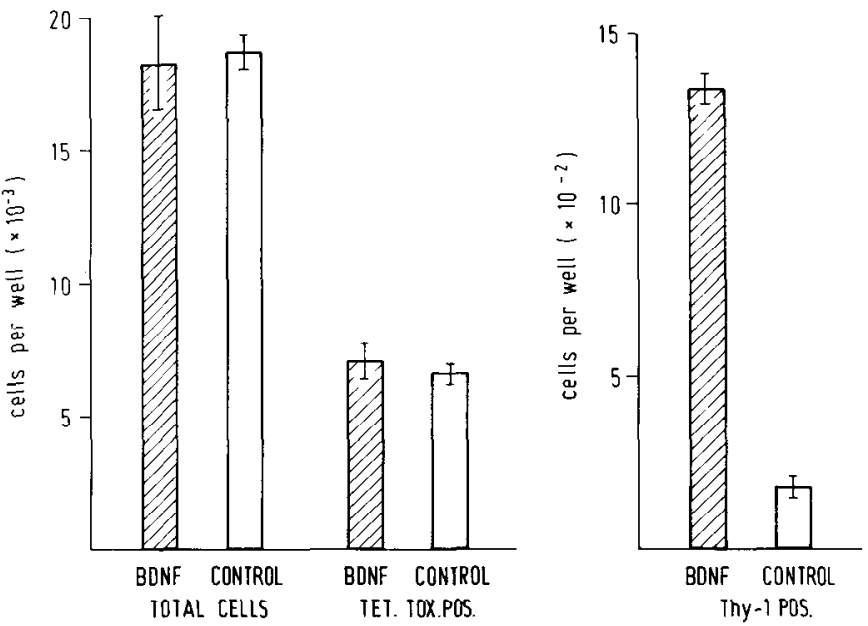

Figure 3. Analysis of the total number of cells, the total number of tetanus toxin-positive neurons (TET. TOX. POS.) and the subpopulation of Thy-1-positive neurons (THY-1 POS.) in E17 retinal cultures grown for $3 \mathrm{~d}$ in the absence (control) or presence of BDNF $(50 \mathrm{ng} / \mathrm{ml}$ ). Note that no significant differences were measured in either the total number of cells or the total number of tetanus toxin-positive neurons after BDNF treatment. The subpopulation of Thy-1-positive neurons, while only a small percentage of the total number of cells, is 9 -fold higher in BDNF-treated cultures. Each value represents the mean of 4 separate measurements $上 \mathrm{SD}$.

seen between cultures treated with or without BDNF (Fig. 3). Nuclei in flat non-neuronal cells were frequently oval, large, and pale blue in fluorescence. In contrast, neuronal nuclei were smaller, spherical, and more intensely fluorescent. Retinal neurons were identified in the same cultures with tetanus toxin localized by indirect immunofluorescence using another wavelength (Figs. 1C, 2C). Tetanus toxin binding has been reported for all types of rat retinal neurons, with the possible exception of photoreceptor cells, in both tissue sections and retinal cultures (Beale et al., 1982). Tetanus toxin-positive neurons varied in both size and morphology. All tetanus toxin-positive neurons developed neurite processes. Fine and highly branched processes

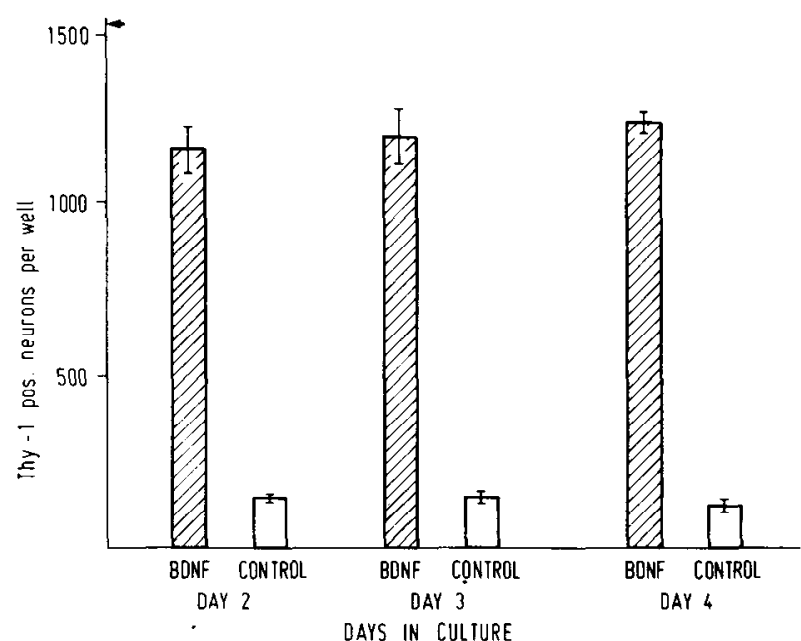

Figure 4. Analysis of the number of Thy-1-positive neurons in cultures prepared from E17 retinas during $4 \mathrm{~d}$ in culture (arrow, original number of Thy-1-positive cells measured $3 \mathrm{hr}$ after seeding). Note that after 2 $\mathrm{d}$ in culture the majority of Thy-1-positive neurons have disappeared in the absence (control) of BDNF, while the number of Thy-1-positive neurons in cultures treated with BDNF $(50 \mathrm{ng} / \mathrm{ml})$ remained constant. Each value represents the mean of 4 separate measurements \pm SD.

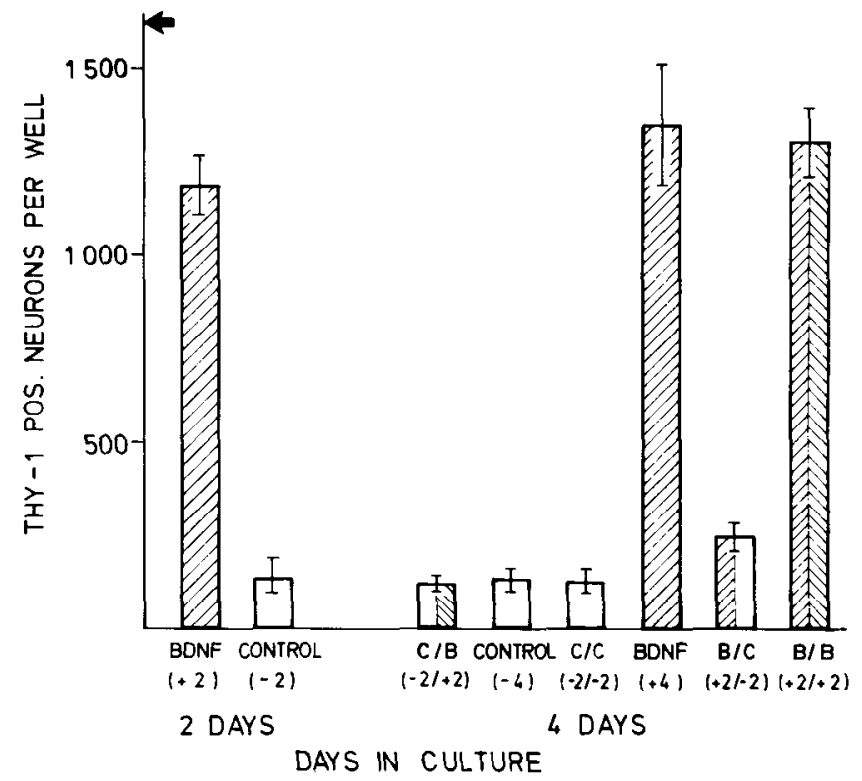

Figure 5. Analysis of the effect of BDNF on the survival of Thy-1positive neurons versus the induction of Thy-1 as a marker. After $2 \mathrm{~d}$ in culture the majority of Thy-1-positive neurons originally plated (arrow) remain in BDNF-treated cultures $(50 \mathrm{ng} / \mathrm{ml})$ but are absent in control cultures. Cultures deprived of BDNF for $2 \mathrm{~d}$ were subsequently treated with BDNF for an additional $2 \mathrm{~d}(C / B,-2 /+2)$ in an attempt to induce Thy- 1 in a surviving population of neurons. These cultures did not differ from control culturcs deprived of BDNF during the entire $4 \mathrm{~d}(-4)$ or control cultures that received a medium exchange without BDNF after $2 \mathrm{~d}$ in culture $(C / C,-2 /-2)$. While cultures treated for 4 $\mathrm{d}$ with BDNF $(+4)$ maintained the number of Thy-1-positive neurons, those initially treated with BDNF for $2 \mathrm{~d}$ and subsequently deprived of BDNF for an additional $2 \mathrm{~d}(B / C,+2 /-2)$ lost the majority of Thy-1positive neurons. This loss could not be attributed to medium exchange alone, since cultures that received a medium exchange with BDNF after $2 \mathrm{~d}$ in culture $(B / B,+2 /+2)$ did not differ from those treated for the entire $4 \mathrm{~d}$ with BDNF $(+4)$.

that were specifically stained for tetanus toxin were sometimes not otherwise readily visible by phase microscopy. The localization of tetanus toxin binding therefore facilitated a quantification of the total number of cultured retinal neurons. Again, no significant difference was seen with or without BDNF (Fig. 3). Using a third wavelength channel, a relatively small subpopulation of all tetanus toxin-positive neurons was also found to be Thy-1 positive (Fig. 2D). Thy-1 staining allowed a marked difference (Fig. 3) to be quantified between cultures treated with or without BDNF. Live neurons labeled for Thy-1 contained a high density of fluorescent clusters, which were found along the surface of the cell body and on neurites (Fig. 2D). Thy-1-positive neurons were typically large, with a diameter greater than 10 $\mu \mathrm{m}$ and a very long process that extended up to $1-2 \mathrm{~mm}$ in culture. These cells increased in their size and complexity in long-term cultures. Whereas tetanus toxin-positive neurons made up about $40 \%$ of all the cells in both BDNF-treated and nontreated cultures (Fig. 3), only about $7 \%$ of the total number of cells in BDNF-treated dishes were Thy-1 positive and less than $1 \%$ in control dishes. Retinal cells frequently appeared to have a slightly more dense network of tetanus toxin-positive neurites when cultured with BDNF. However, no significant differences were measured in the overall number of tetanus toxin-positive neurons (Fig. 3). The presence of a relatively small number of neurons that extend neurites over many fields probably accounts for this apparent increase in the density of the network of neuritcs in BDNF-treatcd cultures. 

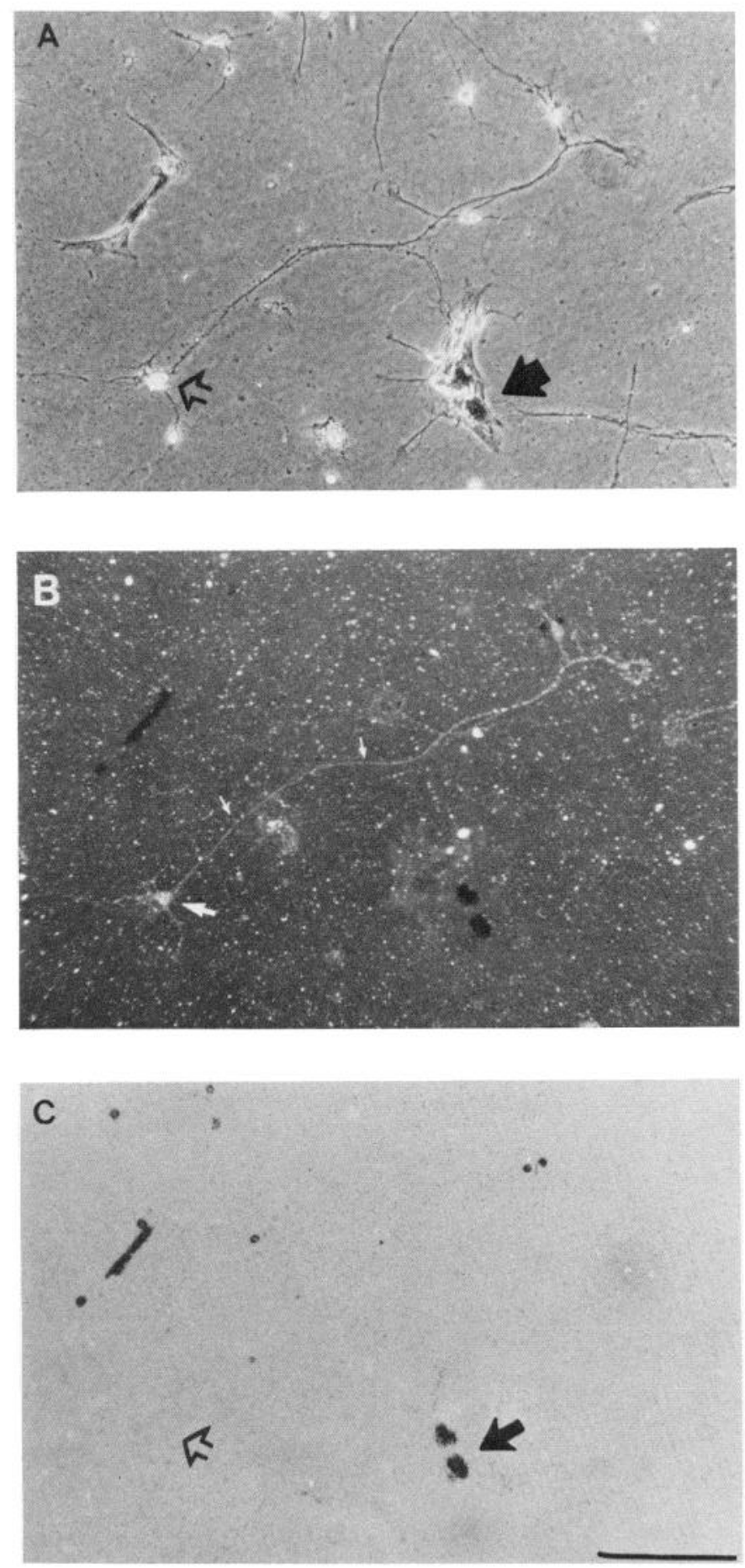

Figure 6. Uptake of ${ }^{3} \mathrm{H}$-thymidine in cells from $\mathrm{E} 17$ retinas treated for $2 \mathrm{~d}$ with BDNF in culture. The same field is photographed with phase microscopy $(A)$, green immunofluorescence of Thy-1 $(B)$, and bright-field illumination of silver grains $(C)$. Note that while some nonneuronal cells are labeled specifically with silver grains over their nuclei (closed arrows in $A$ and $C$ ), the Thy-1-positive neurons are not labeled (open arrow in $A$ and $C$; arrows in $B$ ). Bar (in $C$ ), $100 \mu \mathrm{m}$.

\section{Survival of Thy-1-positive neurons}

Thy-1 was localized on cells dissociated from E17 retinas either $3 \mathrm{hr}$ after seeding or during $4 \mathrm{~d}$ in culture. The original number of Thy-1-positive cells plated was not affected by BDNF treatment $3 \mathrm{hr}$ after seeding. About $1.6 \times 10^{3}$ cells/well, or $7 \%$ of all the originally plated retinal cells, were Thy-1 positive in E17

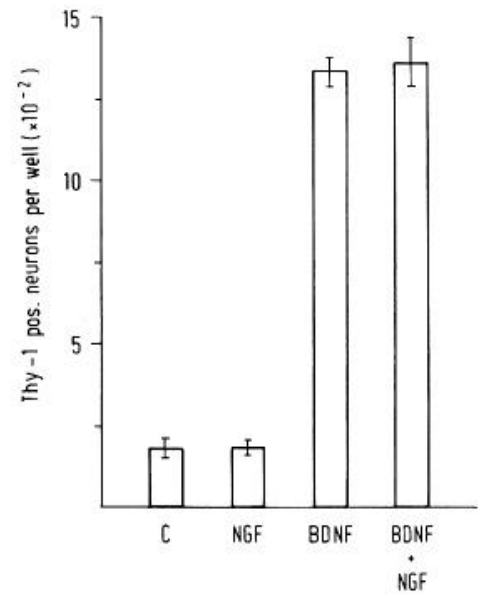

Figure 7. Analysis of the survival of Thy-1-positive neurons in cultures treated with NGF $(50 \mathrm{ng} / \mathrm{ml}), \operatorname{BDNF}(50 \mathrm{ng} / \mathrm{ml}) \mathrm{m}, \operatorname{BDNF}(50 \mathrm{ng} /$ $\mathrm{ml}$ ), or the 2 factors together in equal concentrations. Note that cultures treated with NGF did not-differ from control cultures $(c)$ and that NGF did not potentiate the activity of BDNF on Thy-1-positive neuronal survival. Each value represents the mean of 4 measurements \pm SD.

retinal cultures (arrow, Fig. 5). Approximately $90 \%$ of these cells had disappeared after $2 \mathrm{~d}$ in cultures without BDNF (Fig. 4). This large difference in the number of Thy-1-labeled neurons was maintained by BDNF treatment during $4 \mathrm{~d}$ in vitro. The effect of BDNF was half-maximal at a protein concentration of about $8 \mathrm{ng} / \mathrm{ml}(0.6 \mathrm{nM})$ and saturating at about $20 \mathrm{ng} / \mathrm{ml}(1.6$ $\mathrm{nM})$. These data indicate that in this system BDNF has the same apparent specific activity as that determined with chick spinal sensory neurons or nodose neurons (Barde et al., 1982; Lindsay et al., 1985).

Experiments were conducted to determine if this BDNF-mediated difference in the number of Thy-1-positive neurons resulted from differences in the expression of this glycoprotein used as a label rather than a difference in neuronal survival. Cells were initially cultured for $2 \mathrm{~d}$ in the absence of BDNF and then BDNF was added daily $(50 \mathrm{ng} / \mathrm{ml})$ for an additional $2 \mathrm{~d}$ (Fig. 5). During the initial $2 \mathrm{~d}$, many Thy-1-positive neurons disappeared, as previously noted. The addition of BDNF in cultures originally deprived of the factor did not result in an increase in the number of Thy-1-positive neurons (Fig. 5, C/B). Conversely, cultures with Thy-1-positive neurons maintained by the addition of BDNF during the first $2 \mathrm{~d}$ subsequently lost most of these cells when deprived of BDNF for an additional $2 \mathrm{~d}$ in culture (Fig. 5, B/C). Changes in these cultures could not be attributed to washing alone, since cultures washed but kept subsequently in medium containing BDNF were able to maintain Thy-1-positive neurons (Fig. 5, B/B).

We also checked if the Thy-1-positive cells were recruited by BDNF from a dividing precursor population. Retinal cultures were incubated with ${ }^{3} \mathrm{H}$-thymidine $(1 \mu \mathrm{C})$ for $2 \mathrm{~d}$ and processed for Thy-1 localization and autoradiography (Fig. 6). While a subpopulation of non-neuronal cells was heavily labeled with silver grains over the nuclei (Fig. 6 C), none of the Thy-1-positive neurons was labeled. The number of non-neuronal cells labeled with thymidine did not differ between cultures treated for $4 \mathrm{~d}$ with or without BDNF $\left(1.34 \pm 0.07 \times 10^{4}\right.$ cells/well without BDNF versus $1.3 \pm 0.02 \times 10^{4}$ cells/well with BDNF), as predicted by the analysis of total retinal cells (Fig. 3). NGF ( $50 \mathrm{ng}$ / $\mathrm{ml}$ ) added alone or in combination with BDNF (Fig. 7) did not influence the survival of Thy-1-positive neurons.

\section{Postnatal retinas and retrograde labeling}

Retrograde-labeled retinas were dissociated and analyzed for HRP and Thy-1 staining. Only a small subpopulation of all 

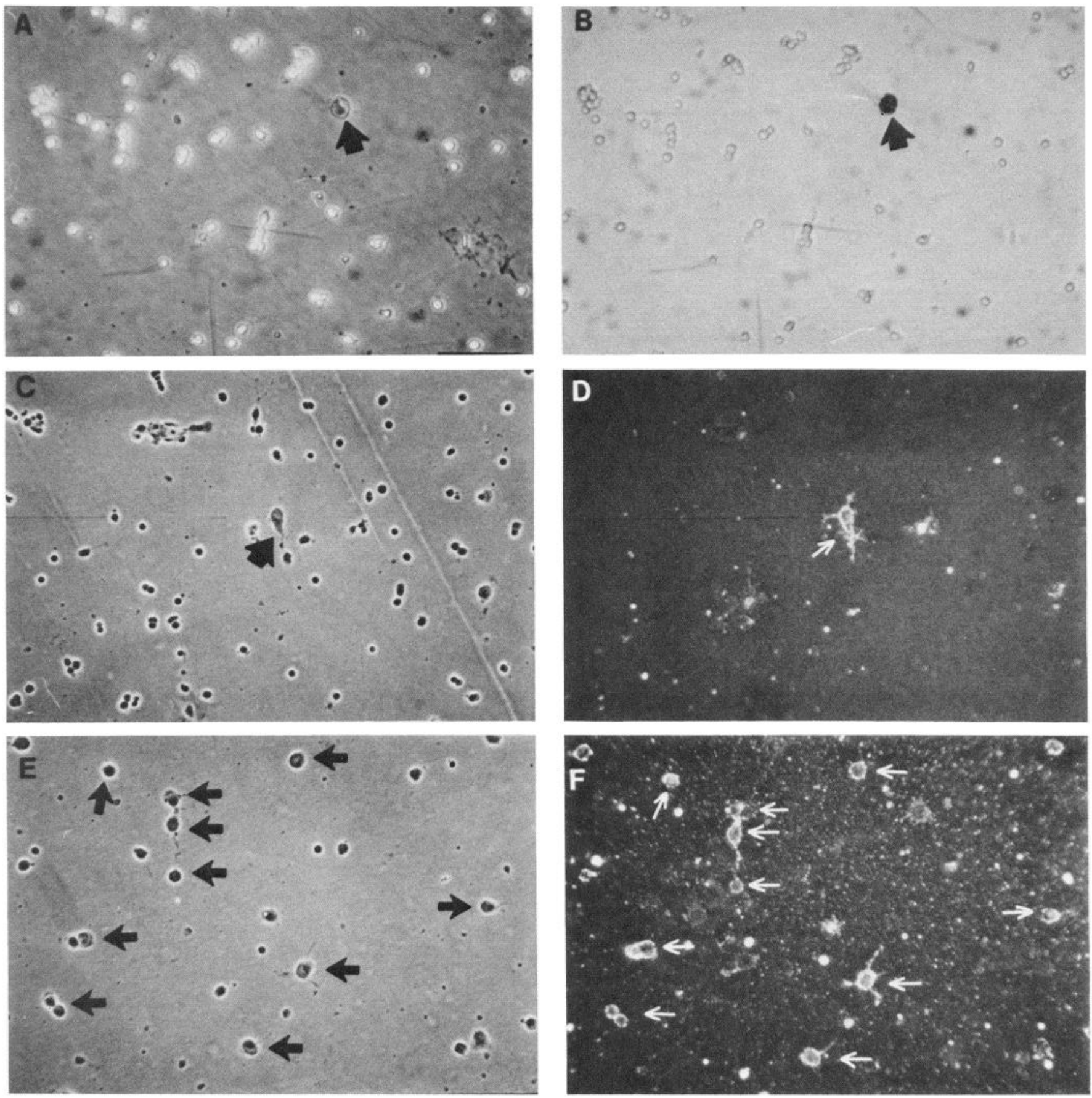

Figure 8. Identification and purification of postnatal rat retinal ganglion cells. Ganglion cells were identified among all other dissociated retinal cells using either retrograde labeling with $\operatorname{HRP}(A, B)$ or Thy-1 immunofluorescence as a marker $(C, D)$. Note that with phase microscopy, only a small subpopulation of large retinal neurons contains HRP reaction product (arrow in $A$ ), which is clearly seen with bright-field illumination (arrow in $B$ ). A similar population of cells (arrow in $C$ ) was specifically labeled with Thy-1 immunofluorescence as well (arrow in $D$ ). These cells could be greatly enriched (arrows in $E$ ) and specifically labeled (arrows in $F$ ) after purification on a metrizamide density gradient. Bar in $A$ is equal to 90 $\mu \mathrm{m}$ in $A$ and $B, 130 \mu \mathrm{m}$ in $C-F$.

retinal cells was labeled with Thy-1 or with HRP (Fig. 8, $B, D$; Table 1). Cells labeled with either marker were similar in their number, size, and morphology. About $1 \%$ of the cells from newborn rat retinas were labeled with Thy- 1 and $0.7 \%$ with HRP (Table 1). These cells could be purified approximately $80-$ fold by a density gradient centrifugation in F14 medium containing metrizamide (see Materials and Methods; Fig. $8 F$ ). Both the purification factor and the recovery of labeled cells were similar using either Thy-1 or HRP as a marker (Table 1). Thy- 1-positive cells made up approximately $90 \%$ of the enriched fraction, while the subpopulation of ganglion cells labeled with HRP contributed about $55 \%$ of these cells in culture. This difference can be accounted for in part by an incomplete labeling of retinal ganglion cells with HRP (see Materials and Methods). The percentage of ganglion cells that responded to BDNF was identical when measured with either Thy-1 or HRP labeling (Fig. 9). Approximately $20 \%$ of the enriched ganglion cells survived for $2 \mathrm{~d}$ in cultures containing BDNF, while almost all of 


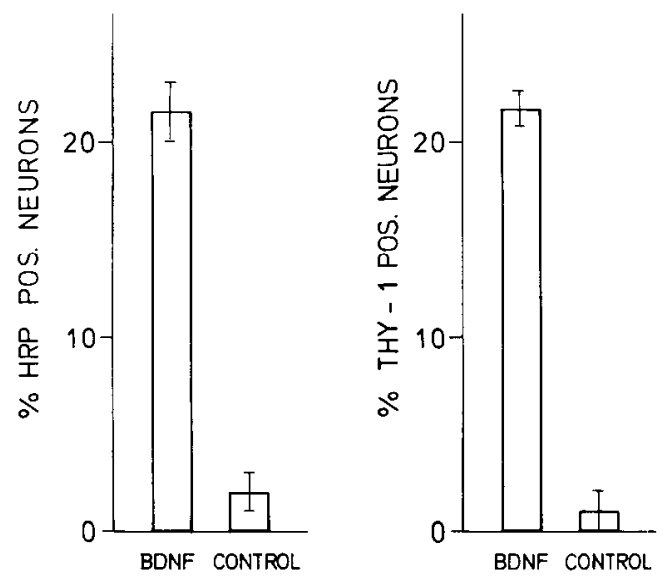

2 DAYS IN CULTURE

Figure 9. Survival of purified cultures of retinal ganglion cells labeled either after HRP labeling in vivo or by immunofluorescent localization of Thy-1. Cultures were grown for $2 \mathrm{~d}$ in the presence or absence of BDNF $(50 \mathrm{ng} / \mathrm{ml})$. Note that while virtually all ganglion cells die in control cultures, an identical percentage of ganglion cells remain in BDNF-treated cultures using either HRP or Thy-1 as a marker. Each value represents the mean of 4 measurements \pm SD.

the labeled ganglion cells died within a few hours after plating in cultures without BDNF. The dose-response of postnatal ganglion cells to BDNF was identical to that previously described for labeled cells in fetal cultures with half-maximal activity at about $8 \mathrm{ng} / \mathrm{ml}$ medium $(0.6 \mathrm{nM})$. Unlike fetal retinal cultures, where all Thy-1-positive neurons showed neurite outgrowth, only about $20 \%$ of the surviving postnatal ganglion cells labeled with either HRP or Thy-1 developed neurite outgrowth. Most of the labeled postnatal ganglion cells died after $4 \mathrm{~d}$ in culture, even in the presence of a saturating concentration of BDNF and in total retinal cell cultures prepared without ganglion cell purification.

\section{Discussion}

Under the conditions used in this study, many of the cells from E17 rat retinas survived in culture, irrespective of the presence or absence of BDNF. This is in contrast to results obtained after treatment with brain extracts, following which global changes were seen in the total number of neurons in culture (Turner, 1985). These differences indicate that complex brain extracts are likely to contain a number of other biological activities in addition to that of BDNF. With BDNF treatment alone, not only were the total cell counts similar with control cultures (Fig. 3), but also those of tetanus toxin-positive neurons (Fig. 3). However, when the cultures were stained for Thy-1, a considerable difference was found. Thy-1 localization revealed a subpopulation of neurons with extremely long processes that was almost absent in cultures without BDNF. In cultures prepared from the total retina, this population represents such a small portion of the total number (about $7 \%$ in E17 retinas) that phasecontrast microscopy, in the absence of Thy-1 staining, is unable to detect a difference between BDNF-treated cultures and untreated cultures. However, Thy-1 staining clearly shows that a large number of Thy-1-positive neurons are seen only when BDNF is added to the cultures, even though the cell density used in this study was high $\left(200\right.$ cells $\left./ \mathrm{mm}^{2}\right)$. These results indicate that under the conditions used in this study, trophic support for the Thy-1-positive cells cannot be provided by the other cells present in culture.

An important question is whether BDNF allows either the survival of a specific, Thy-1-positive population of retinal neurons or the induction of Thy-1 on neurons that are present also

\begin{tabular}{lcl}
\hline Table 1. Retinal ganglion cell purification & \\
& $\begin{array}{l}\text { Total cell } \\
\text { suspension }^{a}\end{array}$ & $\begin{array}{l}\text { Purified } \\
\text { preparation }^{b}\end{array}$ \\
Parameter & $5.0 \times 10^{7}$ & $2.8 \times 10^{5}$ \\
\hline $\begin{array}{l}\text { Total cells } \\
\text { Number of cells }\end{array}$ & 100 & 0.6 \\
\% Recovery & 1.1 & \\
Thy-1-labeled neurons & $1 \times$ & 91.4 \\
\% Thy-1 positive & 100 & $83 \times$ \\
$\begin{array}{l}\text { Purification factor } \\
\text { \% Recovery }\end{array}$ & & 46.5 \\
HRP-labeled neurons & 0.7 & 55 \\
\% HRP positive & $1 \times$ & $78 \times$ \\
Purification factor & 100 & 41 \\
\% Recovery & & \\
\hline
\end{tabular}

Analysis of cells before gradient centrifugation.

${ }^{b}$ Analysis of cells after purification by gradient centrifugation.

in control cultures. The latter possibility was ruled out by the observation that when BDNF was not present in culture initially, but was added 2 days later, no additional Thy-1-positive neurons were seen compared with control cultures. Thy-1-positive cells maintained during the first $2 \mathrm{~d}$ in culture with BDNF were subsequently lost when deprived of the factor for an additional $2 \mathrm{~d}$ in vitro. Also, BDNF does not recruit cells from a dividing pool of precursors, since none of the Thy-1-positive neurons could be labeled with ${ }^{3} \mathrm{H}$-thymidine. In fact, counts of ${ }^{3} \mathrm{H}$-thymidine-labeled cells were identical with or without BDNF (see Results), indicating that BDNF has no mitogenic effect on dividing retinal cells. Finally, the results obtained with postnatal retinas clearly indicate a direct effect of BDNF on Thy-1-positive cells, since these cells make up about $90 \%$ of the total cells after purification on a metrizamide gradient. We therefore conclude that BDNF selectively allows the survival of a (numerically) small, Thy-1-positive population already present and nonmitotic in the E17 rat retina and that, in the absence of BDNF, the majority of this population dies rapidly in dissociated cell cultures. This is reminiscent of observations made with embryonic sensory and sympathetic neurons, which also die very rapidly in culture in the absence of NGF.

Another important question concerns the identity of the Thy1-positive neurons. The morphology of these neurons, their proportion, and the fact that they are postmitotic in the E17 retina strongly suggest that these neurons are ganglion cells, in agreement with the finding that rat retinal ganglion cells are Thy-1 positive. However, it has been reported that while almost all strongly Thy-1-positive cells in the rat retina are ganglion cells, there is a small population of nonganglion cells with weakly Thy-1-positive fibers in the inner plexiform layer (Perry et al., 1984). To establish unambiguously the identity of BDNF-responsive cells as ganglion cells, we retrogradely labeled the retinas of newborn rats by injecting HRP in the superior colliculus bilaterally. This provided an independent means of showing that ganglion cclls do respond to BDNF. In addition, this population of retrogradely labeled and Thy-1-positive cells was responsive to BDNF when enriched about 80 -fold, using a purification technique developed by others (Sarthy et al., 1983). These results indicate that the survival effects of BDNF are direct and do not require the presence of other cclls.

In contrast to prenatal ganglion cells, postnatal cells could not be maintained in culture for several days, even in the presence of optimal concentrations of BDNF. This transient survival of older ganglion cells has been previously reported by other groups, using extracts, cocultures, or conditioned medium from the su- 
perior colliculus (see below). Also, the percentage of labeled postnatal cells supported by BDNF was identical to the survival activity reported in a similar assay using target-derived additives (Sarthy et al., 1983). It is unclear whether this difference in the stability of the cultures of ganglion cells with BDNF prenatal versus postnatal has a physiological meaning or is a consequence of the more severe damage experienced by older cells when cultured.

As previously mentioned, others have reported that postnatal rat ganglion cells can be maintained in culture, at least transiently, by extracts or conditioned media or by coculturing with the target areas of the ganglion cells (Armson and Bennett, 1983; McCaffery et al., 1982; Nurcombe and Bennett, 1981; Sarthy et al., 1983). Furthermore, the target areas (e.g., the superior colliculus) were shown to be considerably supcrior to other areas, such as the cerebellum. We have now shown that retinal ganglion cells isolated during the period of target innervation are responsive to BDNF in vitro. Relevant in this context is the recent observation (Leibrock and Y. A. Barde, unpublished observations) that BDNF is not equally distributed throughout the brain. The concentration of protein needed to obtain half-maximal survival, as measured after the CM-cellulose purification step, is at least 100 -fold smaller in preparations of the superior colliculus than in those of the cerebellum. Based on the NGF targetderived model, which is now convincingly established (Heumann et al., 1984; Korsching and Thoenen, 1983; Shelton and Reichardt, 1984), it is, of course, tempting to speculate that BDNF is the target-derived molecule required by retinal ganglion cells for their survival upon reaching their target area.

\section{References}

Adler, R., J. Jerdan, and A. T. Hewitt (1985) Responses of cultured neural retinal cells to substratum-bound laminin and other extracellular matrix molecules. Dev. Biol. 112: 110-114.

Armson, D. F., and M. R. Bennett (1983) Neonatal retinal ganglion cell cultures of high purity: Effect of superior colliculus on their survival. Neurosci. Lett. 38: 181-186.

Barde, Y. A., D. Edgar, and H. Thoenen (1980) Sensory neurons in culture: Changing requirements for survival factors during embryonic development. Proc. Natl. Acad. Sci. USA 77: 1199-1203.

Barde, Y. A., D. Edgar, and H. Thoenen (1982) Purification of a new neurotrophic factor from mammalian brain. EMBO J. 1: 549-553.

Barde, Y. A., D. Edgar, and H. Thoenen (1983) New neurotrophic factors. Annu. Rev. Physiol. 45: 601-612.

Beale, R., and N. N. Osborne (1982) Localization of the Thy-1 antigen to the surfaces of rat retinal ganglion cells. Neurochem. Int. 4: 581595.

Beale, R., D. Nicholas, V. Neuhoff, and N. N. Osborne (1982) The binding of tetanus toxin to retinal cells. Brain Res. 248: 141-149.

Beale, R., D. W. Beaton, V. Neuhoff, and N. N. Osborne (1983) Enriched populations of rat retinal ganglion cells: Studies using a celltype specific surface marker. Neurochem. Int. 5: 691-696.

Berg, D. K. (1984) New neurotrophic factors. Annu. Rev. Neurosci. 7: 149-170.

Braekevelt, C. R., and M. J. Hollenberg (1970) The development of the retina of the albino rat. Am. J. Anat. 127: 281-302.

Collins, F. (1978) Axon initiation by ciliary neurons in culture. Dev. Biol. 65: 50-57.

Cowan, W. M., C. W. Fawcett, D. D. M. O'Leary, and B. B. Stanfield (1984) Regressive events in neurogenesis. Science 225: 1258-1269.

Crespo, D., D. D. M. O'Leary, and W. M. Cowan (1985) Changes in the numbers of optic nerve fibers during late prenatal and postnatal development in the albino rat. Dev. Brain Res. 19: 129-134.

Davies, A., H. Thoenen, and Y. A. Barde (1986) Different factors from the central nervous system and periphery regulate the survival of sensory neurons. Nature 391: 497-499.

Dreher, B., R. A. Potts, and M. R. Bennett (1983) Evidence that the early postnatal reduction in the number of rat retinal ganglion cells is due to a wave of ganglion cell death. Neurosci. Lett. 36: 255-260.

Fawcett, J. W., D. D. M. O'Leary, and M. Cowan (1984) Activity and the control of ganglion cell death in the rat retina. Proc. Natl. Acad. Sci. USA 81: 5589-5593.
Greene, L., and E. Shooter (1981) Nerve growth factor: Biochemistry, synthesis and mechanism of action. Annu. Rev. Neurosci. 3: 353402.

Heumann, R., S. Korsching, J. Scott, and H. Thoenen (1984) Relationship between levels of nerve growth factor (NGF) and its messenger RNA in sympathetic ganglion and peripheral target tissues. EMBO J. 3: 3183-3189.

Insausti, R., C. Blakemore, and W. M. Cowan (1984) Ganglion cell death during development of ipsilateral retina-collicular projection in golden hamster. Nature 308: 362-365.

Korsching, S., and H. Thoenen (1983) Nerve growth factor in sympathetic ganglia and corresponding target organs of the rat: Correlation with density of sympathetic innervation. Proc. Natl. Acad. Sci. USA 80: 3513-3516.

LaVail, M. M., and J. H. LaVail (1975) Retrograde intraaxonal transport of horseradish peroxidase in retinal ganglion cells of the chick. Brain Res. 85: 273-289.

Levi-Montalcini, R., and P. U. Angeletti (1968) Nerve growth factor. Physiol. Rev. 48: 534-569.

Lindsay, R. M., H. Thoenen, and Y. A. Barde (1985) Placode and neural crest-derived sensory neurons are responsive at early developmental stages to brain-derived neurotrophic factor. Dev. Biol. 112: 319-328.

McCaffery, C. A., M. R. Bennett, and B. Dreher (1982) The survival of neonatal rat retinal ganglion cells in vitro is enhanced in the presence of appropriate part of the brain. Exp. Brain Res. 48: 377-386.

McCaffery, C. A., T. R. Raju, and M. R. Bennett (1984) Effects of cultured astroglia on the survival of neonatal rat retinal ganglion cells in vitro. Dev. Biol. 104: 441-448.

McCaffery, C. A., T. R. Raju, and M. R. Bennett (1985) Retinal ganglion cell survival is mediated by cell contact with immature rat astroglia. Neurosci. Lett. 57: 319-324.

Mesulam, M. M. (1978) Tetramethyl benzidine for horseradish peroxidase neurohistochemistry: A non-carcinogenic blue reaction-product with superior sensitivity for visualizing neural afferents and efferents. J. Histochem. Cytochem. 131: 47-67.

Mirsky, R., L. M. B. Wendon, P. Black, C. Stolkin, and D. Bray (1978) Tetanus toxin: A cell surface marker for neurons in culture. Brain Res. 148: 251-259.

Morest, D. K. (1976) The pattern of neurogenesis in the retina of the rat. Z. Anat. Entwickl. 131: 47-67.

Morris, R. V., and P. C. Barber (1983) Fixation of Thy-1 in nervous tissue for immunohistochemistry: A quantitative assessment of the effect of different fixation conditions upon retention of antigenicity and the cross linking of Thy-1. J. Histochem. Cytochem. 31: 263274.

Nurcombe, V., and M. R. Bennett (1981) Embryonic chick retinal ganglion cells identified "in vitro." Their survival is dependent on a factor from the optic tectum. Exp. Brain Res. 44: 249-258.

Perry, V. H., R. J. Morris, and G. Raisman (1984) Is Thy-1 expressed only by ganglion cells and their axons in the retina and optic nerve? J. Neurocytol. 13: 809-824.

Potts, R. A., B. Dreher, and M. R. Bennett (1982) The loss of ganglion cells in the developing retina of the rat. Dev. Brain Res. 3: 481-486.

Sarthy, R. V., B. M. Curtis, and W. A. Catterall (1983) Retrograde labeling, enrichment, and characterization of retinal ganglion cells from the neonatal rat. J. Neurosci. 3: 2532-2544.

Schneidereit, M. (1985) Study of fetal organ growth in Wistar rats from day 17 to 21. Lab. Anim. 19: 240-244.

Shelton, D. L., and L. F. Reichardt (1984) Expression of the $\beta$-nerve growth factor gene correlates with the density of sympathetic innervations in effector organs. Proc. Natl. Acad. Sci. USA 81: 7751-7955.

Smalheiser, N. R., St. M. Crain, and Lola M. Reid (1984) Laminin as a substrate for retinal axons in vitro. Dev. Brain Res. 12: 136140.

Thoenen, H., and Y. A. Barde (1980) Physiology of nerve growth factor. Physiol. Rev. 60: 1284-1335.

Thoenen, H., and D. Edgar (1985) Neurotrophic factors. Science 229: 238-242.

Turner, J. E. (1985) Promotion of neurite outgrowth and survival in dissociated fetal rat retinal cultures by a fraction derived from a brain extract. Dev. Brain Res. 18: 265-274.

Turner, J. E., Y. A. Barde, M. E. Schwab, and H. Thoenen (1983) Extract from brain stimulates neurite outgrowth from fetal retinal explants. Dev. Brain Res. 6: 77-83. 